\title{
BARTOSz GOLĄBEK
}

Uniwersytet Jagielloński

iD

ORCID https://orcid.org/0000-0001-5679-9761

\section{PISARZ I PROTEST. SZKIC DO DYSYDENCKIEGO PORTRETU BORISA AKUNINA}

\section{THE WRITER AND THE PROTEST:}

\section{A STUDY FOR THE PORTRAIT OF BORIS AKUNIN AS A DISSIDENT}

This article refers to the public biography of the recent years in the life of Boris Akunin, one of the most widely read among contemporary Russian writers. As part of his political activity, Akunin, or Grigori Chkhartishvili, acted under his own name and actively supported the anti-Putin movement during the 2011-2012 protests. The experience gained there and the political events of the last 10 years have left him disappointed and resulted in him becoming an expat. However, mobilized by the circumstances, Akunin launched a new literary project called История Российского Государвства (History of the Russian State), which is conceived as his original attempt to answer some of the perennial questions about Russia. Keywords: Boris Akunin, protests, dissident, Putin, Russia

ПИСАТЕЛЬ И ПРОТЕСТ.

\section{ЭСКИЗ К ДИССИДЕНТСКОМУ ПОРТРЕТУ БОРИСА АКУНИНА}

Настоящая статья отсылает к публичной биографии последних лет одного из самых читаемых современных российских писателей - Бориса Акунина. В рамках своей политической деятельности писатель действовал под своим настоящим именем, активно поддерживая антипутинское движение во время протестов 2011-2012 года. Его жизненный опыт и политические события последних десяти лет принесли значительное разочарование и привели к судьбе эмигранта. Кстати, мобилизованный обстоятельствами 
Акунин основал новый литературный проект под названием «История Российского государства», который должен стать его оригинальной попыткой ответить на вечные русские вопросы.

Ключевые слова: Борис Акунин, протесты, диссидент, Путин, Россия

Poczytny pisarz, a jak woli sam o sobie mówić, beletrysta, Boris Akunin, od 2014 roku tworzy poza granicami Rosji. Chętnie udziela wywiadów prasie, a w jednym z nich podzielił się kontrowersyjną opinią, że jego kraj jest okupowany przez wroga ${ }^{1}$ i dlatego wybrał życie na Zachodzie z - w miarę możliwości rzadkimi - wizytami w rodzimej Moskwie.

Do tego punktu w biografii doprowadziły pisarza liczne wydarzenia, w których odznaczył się jako wpływowy autor, żywo zainteresowany życiem publicznym i działaniami władzy w swoim kraju.

Droga popularnego autora do politycznej aktywizacji otworzyła się ze szczególną intensywnością w roku 2006, w którym rozgorzało napięcie polityczne między Rosją a Gruzją. Dla części europejskiej opinii publicznej interesujący w tej sprawie okazał się głos nie tyle poczytnego pisarza, ile rosyjskiego twórcy o gruzińskich korzeniach, urodzonego w 1956 roku w imeretyńskim miasteczku Zestafoni - Grigorija Czchartiszwilego, bo to przecież właściwe nazwisko beletrysty Borisa Akunina. 9 października 2006 roku na łamach francuskiego lewicowego dziennika „Libération” ukazał się krótki wywiad z Akuninem ${ }^{2}$. W tej rozmowie Czchartiszwili jasno zdefiniował swoją przynależność do kultury rosyjskiej, stwierdził wprost, że mimo pochodzenia czuje się Rosjaninem, a w Gruzji był w dorosłym życiu jedynie raz. Pisarz wypowiedział się w sprawie pogorszenia relacji rosyjsko-gruzińskich właśnie jako zaangażowany i zatroskany ksenofobią współobywateli Rosjanin. Rzeczywiście, wyjątkowo negatywne emocje w Moskwie wywołał marcowy za-

\footnotetext{
${ }^{1}$ Интервью с Борисом Акуниньм - BBC Russian, https://www.youtube. com/watch?v=g3PAJXEiSN8 (10.03.2021). Przekład własny. Wszystkie kolejne tłumaczenia ze źródeł rosyjskich na język polski, o ile nie wskazano inaczej, pochodzą od autora niniejszego tekstu.

${ }^{2}$ Avec la Géorgie, „Poutine agit comme l'empereur Caligula”, https://www. liberation.fr/planete/2006/10/06/avec-la-georgie-poutine-agit-comme-lempereur-caligula_6429/(10.03.2021).
}

RSL.2021.31.05 s. 2 z 21 
kaz władz rosyjskich wydany na import gruzińskich win do Rosji, ale sprawa sporu z prezydentem Saakaszwilim miała poważniejszy kontekst polityczny z energetyką w tle. W styczniu 2006 roku Tbilisi obwiniło Moskwę o celowe wywieranie nacisku politycznego poprzez dywersyjne wysadzenie ważnej dla Zakaukazia magistrali gazowej Mozdok-Tbilisi. Jeszcze jednym problemem, który eskalowała Moskwa, aby osłabić niezależność ambitnego prezydenta Gruzji, była obecność rosyjskich sił pokojowych w dążącej do secesji Osetii Południowej. Porozumienie rosyjsko-gruzińskie w tej sprawie obowiązywało od czerwca 1992 roku. Kryzysowy rok 2006 zwieńczył skandal szpiegowski i zawieszenie lotów na trasie Moskwa-Tbilisi. Jak wiemy, najgorsze w najnowszych relacjach gruzińsko-rosyjskich miało jednak dopiero nastąpić latem 2008 roku. Akunin nie wdawał się w detale geopolitycznej rozgrywki władz Rosji z Gruzją. Stwierdził jedynie, że podejmowane decyzje i nastroje stymulowane przez moskiewskich liderów rodzą niebezpieczną atmosferę protofaszyzmu, z którą trudno mu się pogodzić3.

Po krytycznym wobec bieżącej sytuacji w Rosji wywiadzie, który dotyczył przede wszystkim kwestii gruzińsko-rosyjskich, Akunin nie kontynuuje publicystycznej aktywności. Zażenowanie sytuacją w kraju skłoniło go jednak do zabrania głosu w 2008 roku. Stało się to akurat w pierwszym roku prezydentury Dmitrija Miedwiediewa, po słynnej — dodajmy pierwszej — zamianie stanowiskami z Władimirem Putinem. Z punktu widzenia wątku gruzińskiego ważne także, że stało się to już po eskalacji konfliktu między Rosją i Gruzją o Osetię Południową, który przerodził się w krótkotrwałą wojnę. Do zabrania głosu w sprawach publicznych i politycznych zachęciła Akunina propozycja z rosyjskiego wydania czasopisma „Esquire”, któremu odpowiedział:

\footnotetext{
${ }^{3} \mathrm{~W}$ przedruku i przekładzie na język rosyjski tego wywiadu dla portalu Inosmi.ru (https://inosmi.ru/world/20061009/230352.html) (8.03.2021) ujęta została jeszcze jedna odpowiedź dotycząca zaangażowania politycznego Akunina. Pisarz stwierdził, że dotąd nie angażował się ani w trakcie kryzysu terrorystycznego w teatrze na Dubrowce (2002), ani podczas procesu firmy JUKOS. W tym przypadku jednak nie mógł milczeć. Autor niniejszego opracowania nie odnalazł jednak tego ważnego fragmentu w aktualnie dostępnym internetowym wydaniu tekstu dziennika „Libération”.
} 
„Najbardziej ciekawiłaby mnie rozmowa z Michaiłem Chodorkowskim"4.

Wydawca czasopisma przygotowywał numer, w którym tzw. znani ludzie mieli przeprowadzać wywiady z innymi sławami. Redaktorem naczelnym czasopisma był wówczas Filipp Bachtin, pod którego przewodnictwem pismo było postrzegane jako antyreżimowe ${ }^{5}$. Akunin, do którego czasopisma lifestylowe wielokrotnie zwracały się o teksty, ukuł sobie odpowiedź, że chce napisać tekst o więzionym biznesmenie Chodorkowskim. Zazwyczaj rozmowa $\mathrm{z}$ wydawcą na tym się kończyła, ale w 2008 roku redakcja „Esquire” nie spłoszyła się i przyjęła tę zaskakującą propozycję. Pisarz zastrzegł jednak, że podejmie się tego pod warunkiem, że nie będzie w tekście żadnej dodatkowej redakcji czy skrótów. Najwyraźniej warunki zostały dotrzymane, ponieważ wywiad opublikowano. Pierwszy wyrok w sprawie Chodorkowskiego ogłoszono 31 maja 2005 roku$^{6}$. Trafił on do kolonii karnej w Krasnokamieńsku w Kraju Zabajkalskim. Wywiad, który ukazał się drukiem w październikowym numerze „Esquire”, mógł się odbyć wyłącznie w trybie korespondencyjnym. Chodorkowski jesienią 2008 roku był przetrzymywany w więzieniu w Czycie ${ }^{7}$, w znacznie gorszych warunkach niż te, któ-

\footnotetext{
${ }^{4}$ To wstęp do wywiadu opublikowanego w zbiorze: M. Chodorkowski, Będę walczył o wolność, przeł. J. Redlich, Wydawnictwo Albatros A. Kuryłowicz, Warszawa 2011, s. 95. Jest to polskie wydanie książki Cmaтьu, диалоги, интервью, która w Rosji ukazała się nakładem wydawnictwa Eksmo. Oryginalny wywiad Czchartiszwilego z Chodorkowskim nie jest dostępny $\mathrm{w}$ archiwum internetowym „Esquire”, ale jego skan $\mathrm{z}$ drukowanego czasopisma można odnaleźć w archiwalnym portalu www.khodorkovsky.ru, https://old. khodorkovsky.ru/media/8737_Esquire_Interview_MBK-Rus.pdf (8.03.2021).

${ }^{5}$ Taka teza, oparta między innymi na skandalizującej wielkoformatowej reklamie z okładką numeru kwietniowego z 2010 roku z pytaniem Po co baleriny i geje dołaczaja do partii Jedinaja Rossija, pada w wywiadzie z Bachtinem dla pisma „LookAtMe” z 4.10.2019 - Прямая речь: главный редактор Esquire Филипп Бахтин, http://www.lookatme.ru/mag/archive/experience-interview/106931filipp-bahtin-2010-10-03 (10.03.2021).

${ }^{6}$ M. Chodorkowski, N. Gieworkian, Więzień Putina, przeł. A. Sowińska, AgoraWydawnictwo Czarne, Warszawa 2012, s. 22.

${ }^{7}$ Dokładnie 8 października 2008 roku sąd okręgowy w Czycie przedłużył decyzję o zatrzymaniu Chodorkowskiego w zakładzie karnym do lutego 2009 roku, https://www.newsru.com/russia/08Oct2008/mike.html (10.03.2021).
}

RSL.2021.31.05 s. 4 z 21 
re miał w kolonii. Akunin w wywiadzie podpisuje się swoim rzeczywistym imieniem i nazwiskiem, taką formułę przyjął również dla wszystkich swych tekstów eseistycznych i naukowych - tu występuje jako badacz bądź obywatel Czchartiszwili. We wstępie do rozmowy wyjaśnia, skąd pomysł na dyskusję z rosyjskim więźniem numer 1:

Właśnie na procesie Jukosu straciliśmy niezawisłość sądu - instytucji, bez której nie może istnieć społeczeństwo demokratyczne. To znaczy, że do tego punktu należy wrócić. Jeżeli przywróci się sprawiedliwość i praworządność w sprawie Chodorkowskiego, pomoże się również wszystkim innym ofiarom naszej okulałej Temidy ${ }^{8}$.

Rozmowa sprawia wrażenie emocjonalnie wyrównanej, daje się wyczuć, że Akunin - Czchartiszwili podchodzi do swego rozmówcy z obiektywizmem, stara się dowiedzieć jak najwięcej o poglądach swego respondenta bez uprzednich założeń bądź tez: „pomówmy bez taryfy ulgowej z powodu więzienia. Ono, przeklęte, jest obecne, ale dla idei krat nie ma"9. Jednym pewnym, łączącym korespondentów elementem jest niewątpliwie przekonanie o upadku rosyjskiego sądownictwa, ale dalsza część wywiadu jest dynamiczna i odkrywcza dla obu stron. Chodorkowski wyjawia domniemane przyczyny swojej banicji, podaje wiele nazwisk wysoko postawionych urzędników kremlowskich, którzy stymulowali proces i w jakimś sensie skorzystali na odosobnieniu szefa Jukosu i rozbiciu jego firmy. Pisarz natomiast ujawnia swoje zainteresowanie osobowością Chodorkowskiego, motywacją jego decyzji o pozostaniu w kraju. Chodorkowski otrzymywał bowiem sygnały, że rosyjski wymiar sprawiedliwości szykuje się do jego zatrzymania, ale mimo ostrzeżeń nie skorzystał z możliwości ucieczki za granicę ${ }^{10}$.

\footnotetext{
${ }^{8}$ M. Chodorkowski, Będę walczył o wolność..., s. 95-96.

${ }^{9}$ Tamże, s. 116.

${ }^{10}$ Potwierdza to zarówno w rozmowie z Akuninem, jak i w bieżących wystąpieniach, np. w upublicznionym pod koniec 2020 roku trzyipółgodzinnym wywiadzie z ukraińskim dziennikarzem i publicystą Dmitrijem Gordonem na jego kanale na YouTube, https://www.youtube.com/watch?v=hqkRgYuaMsg\&t (8.03.2021).
} 
Znaczący jest fragment wywiadu poświęcony zagadnieniu archetypowej odpowiedzialności mężczyzny. Pisarz dzieli męskie sprawy na dwa światy: Mały i Wielki. To rzeczywistości, między którymi trzeba dokonywać wyboru. Wedle tej wizji, Mały Świat to rodzina i bliscy, a Wielki - życie zawodowe, wiara, działalność publiczna. Z pewną estymą odnosi się do Chodorkowskiego, który idąc pod sąd, poświęcił swoje zobowiązania wobec Małego Świata.

Czchartiszwili przystąpił do tej rozmowy niewątpliwie dobrze przygotowany, po sumiennej lekturze tekstów Chodorkowskiego, które - w miarę możliwości - przesyłał za pośrednictwem adwokatów do różnych mediów od momentu aresztu. Dały one dobre podłoże do swego rodzaju polemiki między rozmówcami, reprezentującymi zasadniczo wspólny, liberalny punkt widzenia na sprawy publiczne. Wywiad zatem ma bardzo aktualny charakter, odczytuje się go jak debatę intelektualistów - tak modny w rosyjskiej przestrzeni medialnej public talk. W pewnym momencie Czchartiszwili nawet żartuje, że w wymiarze ideowym i formalnym ich dialog zaczyna być parodią znanego historykom myśli rosyjskiej epistolarnego sporu Wissariona Bielińskiego z Nikołajem Gogolem z połowy XIX wieku ${ }^{11}$.

Najciekawsze z punktu widzenia niniejszego szkicu są te polemiczne fragmenty wywiadu, w których autor cyklu kryminalnego o Eraście Fandorinie uwypukla swoje liberalne poglądy, jednocześnie podkreślając, że demokracja nie może powstać inną drogą niż tą „od korzeni”. Liberalizm kojarzony z bogaceniem się kolejnych grup społecznych nie musi pozostawać jedynym wariantem rozwoju wolności w Rosji. Z publicystycznym zapałem prowokuje przy tym, lewicującego pod wpływem życiowych doświadczeń Chodorkowskiego, do refleksji pytaniem z tezą:

Liberalizm nie jest władzą „szmalu nad złem”. W nim w ogóle nie chodzi o pieniądze, chodzi o poczucie własnej godności. Nie mogę już słuchać pomstowania na „przeklęte lata dziewięćdziesiąte”. Gdzie byśmy teraz wszyscy byli bez tych lat dziewięćdziesiątych? Nie można się wyrzekać liberalizmu tylko dlatego, że część liberałów (nie najlepsza, ale po prostu najsprytniejsza) wprzęgła się w wóz i nie uciągnęła. To tylko znaczy, że demokracja nie dotrze do nas z góry, ale drogą naturalną, czyli trudną — „od korzeni”, od dołu. Stara prawica powin-

${ }^{11}$ M. Chodorkowski, Będę walczył o wolność..., s. 123.

RSL.2021.31.05 s. 6 z 21 
na jak najszybciej odejść - ostatecznie się zdyskredytowała. Zastąpi ją nowa prawica, która właśnie będzie budować społeczeństwo obywatelskie $\mathrm{z}$ dołu do góry, a nie z góry na dół. Budować według tych samych odwiecznych wzorów: szacunek do praw człowieka, tolerancja, niekrzykliwe męstwo, patriotyzm bez ksenofobii. Wyrażając się językiem rodzimej ulicy, wszystko to co sprowadza się do formuły: „nie giąć karku przed silnym i nie gnębić słabego”. Pan się nie zgadza? Proszę oponować12.

Przytoczony passus to jedno z najściślej wyrażonych w pisemnej formie ideowych credo Czchartiszwilego. Fragment nie został spisany z jakiejś nagranej wiecowej bądź innej publicznej wypowiedzi, konstruowanej często ad hoc pod wpływem chwili i emocji, ale został z namysłem zapisany i zredagowany, tak jak życzył sobie tego autor.

Realne zaangażowanie pisarza w działalność polityczną przypada na przełomowy dla antyputinowskiego ruchu opozycyjnego rok 2011. Warto pokrótce przypomnieć, że głównym zapalnikiem powodującym rozbudzenie emocji politycznych w Rosji był jesienny projekt władzy, polegający na hermetyzacji status quo. W zasadzie, z punktu widzenia rządzących, unieważniał on zbliżający się cykl wyborczy - grudniowe wybory do Dumy Państwowej oraz przypadające na 2012 rok wybory prezydenckie - poprzez utrzymanie na kluczowych stanowiskach w państwie Putina oraz Miedwiediewa. Dla wielu obserwatorów sceny politycznej, w dniu podania tej decyzji, zniweczone zostały wszelkie nadzieje (jeśli ktoś je jeszcze pielęgnował) na liberalizację polityki rosyjskiej i ostateczne pogrzebanie tezy o niezależności Miedwiediewa. Pojawiły się także opinie, że Miedwiediew używał bardzo często liberalnych haseł, które pobudzały apetyt na zmiany, a kremlowscy eksperci nie zauważyli licznych sprzeczności w tym przekazie.

Od połowy 2009 roku coraz więcej osób dołączało do, stosunkowo nielicznych początkowo, moskiewskich protestów w obronie 31 artykułu rosyjskiej konstytucji, gwarantującego swobodę zgromadzeń ${ }^{13}$. Jesienią sytuacja zaczęła eskalować. Do dość powszechnego

\footnotetext{
${ }^{12}$ Tamże, s. 117.
}

${ }^{13}$ M. Bennetts, Dokopać Kremlowi. Walka rosyjskich dysydentów o odsunięcie Putina od władzy, przeł. J. Wąsiński, P. Wolak, Muza S.A., Warszawa 2014, s. 93. 
zniechęcenia środowisk opozycyjnych wobec projektu tandemu władzy doszły jednak problemy z utrzymaniem stabilności systemu podczas wyborów parlamentarnych. Po wyborach do Dumy Państwowej, które z licznymi naruszeniami na wielu poziomach odbyły się 4 grudnia 2011 roku, środowiska opozycyjne różnych skrzydeł zaczynają organizować akcje protestacyjne, w tym najliczniejszą w historii rosyjskich protestów po 1991 roku na Placu Błotnym w Moskwie. Wedle różnych danych moskiewski protest „3a честные выборы" (O uczciwe wybory) zebrał co najmniej 35 tysięcy protestujących z rozmaitych stron rosyjskiej sceny politycznej. Wśród występujących na scenie był także Czchartiszwili, którego zwięzłe i konkretne przemówienie zostało ocenione przez „dekabrystów Placu Błotnego"14 jako jedno z najbardziej trafnych w tym historycznym momencie. Pisarz w swym krótkim wystąpieniu sformułował kilka postulatów, które protestujący powinni donieść do Kremla. Wśród nich były żądania organizacyjne i polityczne. Do tych pierwszych zaliczyć należy postulat o powołaniu komitetu koordynacyjnego protestów i zespołu negocjacyjnego z władzami złożonego z trzech osób cieszących się zaufaniem wszystkich sił opozycyjnych. Wątki stricte polityczne to: sformułowanie żądania odnośnie do ponowienia wyborów w Moskwie, z transmisją online z każdego lokalu do końca liczenia głosów ${ }^{15}$, przedterminowe rozwiązanie Dumy Moskiewskiej i przeprowadzenie nowych lokalnych wyborów, obywatelskie wybory mera Moskwy. Czchartiszwili zakończył swe przemówienie sentymentalnym spostrzeżeniem: „Dwadzieścia lat nie widziałem takiej Moskwy. Szczerze mówiąc, myślałem, że takiej jej już nie zobaczę. Dziś jest bardzo ważny dzień w moim i w naszym wspólnym życiu" ${ }^{16}$.

\footnotetext{
${ }^{14}$ Określenie z artykułu w serwisie internetowym rosyjskiego wydania „Deutsche Welle", https://p.dw.com/p/13QVM (12.03.2021).

${ }^{15}$ Idea ta faktycznie została wdrożona do procesu wyborczego w Rosji w wyborach prezydenckich w 2012 roku, ale dosyć łatwo się skompromitowała. Zob. B. Gołąbek, Anatomia „Runetu”. Rosyjskojęzyczny internet jako extra territorium byłego ZSRR, Państwowa Wyższa Szkoła Zawodowa w Krośnie, Krosno 2014, s. 94-95.

${ }^{16}$ Nagranie wystąpienia Akunina na demonstracji na Placu Błotnym w Moskwie
} 
Wszystko wskazuje na to, że przeciwnicy zaangażowania pisarza w sprawy polityczne dostrzegli jego aktywność, ponieważ nocą z 18 na 19 grudnia 2011 roku hakerzy włamali się na blog Akunina $\mathrm{w}$ serwisie LiveJournal i usunęli wszystkie jego wpisy ${ }^{17}$, które, szczęśliwie dla autora i jego fanów, udało się przywrócić.

Akunin bardzo zaangażował się w działalność ruchu protestacyjnego w grudniu 2011 roku. Wspierany między innymi przez Borisa Niemcowa, został jednym z aktywnych członków komitetu organizującego kolejną wielką demonstrację 24 grudnia 2011 roku. Niemcow z niejakim trudem formował wiarygodną ekipę firmującą akcje protestacyjne, padały w tej kwestii pytania o polityków i o obywatelski wymiar ruchu. Społeczny charakter formacji protestu mieli autoryzować działacze kultury, między innymi dziennikarz i twórca telewizyjny Leonid Parfionow, Boris Akunin czy popularna aktorka Lija Achedżakowa ${ }^{18}$.

Wystąpienie Czchartiszwilego 24 grudnia przed kilkudziesięciotysięcznym tłumem, w przeciwieństwie do przemowy na Placu Błotnym, było już znacznie bardziej agresywne i emocjonalne, miało też wyraźnie wiecowy i mobilizujący charakter, co trudno powiedzieć o wystąpieniu z 10 grudnia. Kwestia fałszerstw wyborczych z Placu Błotnego zamieniła się, przynajmniej w kontekście jego przemówienia, już w protest czysto antyputinowski przed kolejnymi ustawionymi wyborami prezydenckimi w zbliżającym się 2012 roku. Akunin w swoim niemal pięciominutowym wystąpieniu na prospekcie Sacharowa był twardy, zaapelował o odesłanie prezydenta Putina na emeryturę. Nawoływał do zebrania w okresie noworocznym sił i myśli w sprawie wyborów prezydenckich, wybo-

10 grudnia 2011 roku z profilu YouTube partii Jabłoko TV, https://www.youtube. com/watch?v=Md8G3pSX91E (11.03.2021).

${ }^{17}$ Писатель Борис Акунин - о том, как называется то, что происходит сейчас в России, https://www.svoboda.org/a/24426640.html (12.03.2021).

${ }^{18}$ Wywiad z Niemcowem z 26 grudnia 2011 roku, https://www.svoboda. org/a/24435229.html (8.03.2021). W Internecie zachowały się nagrania $z$ negocjacji liderów środowisk opozycyjnych, w których próbują ustalić wspólną strategię działań protestacyjnych. W konferencji prasowej zorganizowanej przed demonstracją 24 grudnia Akunin siedzi naprzeciw Niemcowa, wraz z Parfionowem reprezentując w społecznym ruchu skrzydło świata kultury.

RSL.2021.31.05 s. 9 z 21 
ru jednego kandydata, który spodoba się całej „uczciwej Rosji”, jak nazwał protestujące środowisko.

Po jednoznacznym zwycięstwie wyborczym Putina w wyborach prezydenckich Czchartiszwili porzucił rolę zaangażowanego aktywisty na rzecz komentatora-publicysty. 13 maja 2012 roku Akunin chyba po raz ostatni wziął jeszcze udział w opozycyjnej akcji ulicznej. W towarzystwie pisarzy Dmitrija Bykowa, Ludmiły Ulickiej, Dmitrija Głuchowskiego, satyryka i dziennikarza Wiktora Szenderowicza, muzyka Andrieja Makarewicza, wraz z co najmniej kilkoma tysiącami protestujących uczestniczył w tzw. spacerze kontrolnym od Placu Puszkina do Czystych Prudów ${ }^{19}$. Marsz miał sprawdzić reakcję służb bezpieczeństwa, tym razem dość biernych wobec pokojowo demonstrujących opozycjonistów. Przed inauguracją prezydencką i po jej zakończeniu, służby bezpieczeństwa zdecydowanie rozpędzały wszelkie przejawy ulicznej aktywności opozycjonistów, choć jedna z grup zdołała założyć mobilne obozowisko, które ze względu na pobliski pomnik kazachskiego poety Abaja otrzymało nieformalną nazwę „ОккупайАбай”, nawiązującą do nowojorskiej akcji protestu na Wall Street.

Znamienny jest jego obszerny wpis na blogu z dnia 12 sierpnia 2012 roku pod tytułem F.A.Q. Tekst Akunina to właściwie odpowiedź na często zadawane mu pytania (F.A.Q. - $\mathrm{z}$ angielskiego - frequently asked questions) związane z politycznymi realiami powyborczej Rosji. Latem 2012 roku Duma Państwowa uchwaliła szereg ustaw, które zaciskały kontrolę państwa nad aktywnością społeczną - między innymi słynną ustawę o zgromadzeniach i tzw. ustawę „o agentach zagranicznych" ${ }^{20}$. Mimo to w poglądach pisarza na przyszłość dla opozycji wciąż rysowała się nadzieja na zmiany - Czchartiszwili zakładał, że możliwe jest odsunięcie Putina od władzy w 2014 roku²1.

${ }^{19}$ В Москве прошла „контрольная прогулка” с писателями?, https://www. bbc.com/russian/russia/2012/05/120513_moscow_progulka (10.03.2021).

${ }^{20}$ Nowelizacja ustawy o organizacjach pozarządowych z 13 lipca 2012 roku zaostrzająca kontrolę państwa nad NGO korzystającymi z zagranicznego wsparcia finansowego.

${ }^{21}$ Wpis na blogu Akunina z 12 sierpnia 2012 roku pt. F.A.Q, https://borisakunin. livejournal.com/71491.html (10.03.2021).

RSL.2021.31.05 s. 10 z 21 
W antyputinowskim zaangażowaniu Akunina należy odnotować jeszcze jeden epizod z jesieni 2013 roku. 20 listopada pisarz zakomunikował na swoim profilu w sieci społecznościowej Facebook, że nie zamierza się pojawić na zapowiedzianym na kolejny dzień spotkaniu rosyjskich pisarzy z prezydentem Putinem. Swą odmowę przyjęcia zaproszenia na Kreml argumentował przetrzymywaniem przez władze Rosji więźniów politycznych. Popularność pisarza i zasięg tego wpisu zmobilizowały rzecznika Kremla Dmitrija Pieskowa do skomentowania tego stanowiska, który w swej dość sztampowej wypowiedzi stwierdził, że słowa pisarza nie mają związku z realiami i określił go „społecznym nihilistą”22.

Jednak w grudniu 2013 roku, jak się powszechnie uważało, ze względu na wizerunek zbliżających się XXII Zimowych Igrzysk Olimpijskich w Soczi, doszło do przedterminowego zwolnienia z więzienia wyrazistych antyreżimowych postaci: Michaiła Chodorkowskiego oraz Nadieżdy Tołokonnikowej i Marii Aliochiny z grupy Pussy Riot $^{23}$. Dla Czchartiszwilego była to emocjonalna kolejka górska, bo jednocześnie późną jesienią 2013 roku rewolucyjny nastrój ogarnął Kijów. Prezydent Wiktor Janukowycz odmówił ratyfikacji umowy stowarzyszeniowej z Unią Europejską, czym sprowokował burzliwą reakcję, najpierw studenckiej młodzieży ukraińskiej stolicy, a następnie części proeuropejsko nastawionego społeczeństwa Ukrainy.

Kaskada wydarzeń na początku 2014 roku w zbuntowanej Ukrainie prowadziła kraj w nieznane. Opinię światową zaskoczyła także reakcja Kremla, który wokół wydarzeń na Euromajdanie zbudował, doskonale oddziałującą na masy rosyjskich i rosyjskojęzycznych telewidzów, akcję propagandową. Ofiary śmiertelne zamieszek w Ki-

22 Дмитрий Песков: отказ Бориса Акунина от участия в титсобрании - „общественныц нигилизм”, https://www.kommersant.ru/doc/2348322 (10.03.2021).

${ }^{23}$ Były to politycznie stosunkowo niekosztowne, ale wizerunkowo pożyteczne gesty Putina. Chodorkowski został właściwie ułaskawiony na własny wniosek skierowany do Putina - chodziło mu o spotkanie z ciężko chorą matką. Do końca odbycia kary pozostawało mu jeszcze osiem miesięcy. Skandalizujące happenerki z grupy Pussy Riot w dniu zwolnienia miały do końca wyroku jeszcze trzy miesiące.

RSL.2021.31.05 s. 11 z 21 
jowie, niejasna ucieczka Janukowycza z Ukrainy i eskalujący kryzys polityczny zaowocowały zaskakującymi także dla Rosjan działaniami Putina: zbrojnym oderwaniem od rozchwianej Ukrainy Półwyspu Krymskiego, które usankcjonowano - nieuznawanym w społeczności międzynarodowej - przeprowadzonym pod lufami nieoznakowanych żołnierzy, tzw. zielonych ludzików, referendum 16 marca 2014 roku. A później była już tzw. Russkaja Wiesna w ukraińskim Donbasie, czyli wojna, której „Kreml nie prowadzi”, a rosyjscy mężowie, ojcowie i synowie dobrowolnie idą tam pod obstrzał ${ }^{24}$. Wracając do emigracji Akunina, jasne jest, że opuszczenie przez pisarza ojczyzny nie jest związane wyłącznie z patriotyczno-nacjonalistycznym wzmożeniem Rosji, które wybuchło po aneksji Półwyspu Krymskiego w 2014 roku. Na decyzję pisarza złożyło się wiele politycznych doświadczeń i osobisty zawód, którego doświadczył po fiasku swego aktywnego zaangażowania politycznego. Napisał o tym w swoim blogu w grudniu 2014 roku, już z dala od Moskwy:

5 grudnia 2011 roku nie było mnie w Moskwie. Zupełnie nie zrozumiałem, jak i dlaczego na Czystych Prudach wydarzyło się to, co się wydarzyło. Pamiętam, że przeżywałem wówczas dwa silne uczucia: zaskoczenie i radość. [...] Wróciłem i na miarę swoich sił i wyobrażeń o słuszności tych działań wziąłem w tym udział. Nie pchałem się do przywództwa, to nie w moim charakterze, ale dużo rozmawiałem z liderami - przekonywałem, starałem się wpływać na ich decyzje (niezbyt skutecznie) ${ }^{25}$.

Bardzo ważne są w tej sprawie także pewne frustracje związane z brakiem szerokiego społecznego zrozumienia dla antyputinowskich wartości politycznych, które pisarz reprezentuje - wszakże sporo $z$ tych ludzi to jego czytelnicy! To także fanami literatury Akunina zawładnęły euforyczne emocje związane $\mathrm{z}$ przywracaniem do rosyjskiej macierzy utraconych w 1991 roku terytoriów.

Warto tu przypomnieć, że obok masowego entuzjazmu zwykłych Rosjan, dość łatwo zresztą stymulowanego i podsycanego przez

\footnotetext{
${ }^{24} \mathrm{~J}$. Kostiuczenko, Przyszło nam tu żyć. Reportaże z Rosji, przeł. K. Kwiatkowska-Moskalewicz, Wydawnictwo Czarne, Wołowiec 2020, s. 319.

${ }^{25}$ Wpis z 13 grudnia 2014 roku, Осторожно, двери закрываются. Следующая остановка... (записки ветерана), https://borisakunin.livejournal.com/139777. html (10.03.2021).
}

RSL.2021.31.05 s. 12 z 21 
rządowe media, swe wyrazy poparcia dla prezydenta Rosji zgłaszali w trakcie ukraińskiego kryzysu także liczni działacze kultury. Szczególną rolę odegrali niewątpliwe ci, podpisani pod słynnym krymskim listem poparcia, opublikowanym na łamach gazety „Известия” 11 marca 2014 roku $^{26}$, a wykaz nazwisk jest dość długi. Dwa dni po publikacji listu poparcia dla Putina, równie spora grupa ludzi kultury wystąpiła $\mathrm{z}$ kontrpropozycją $-\mathrm{z}$ antywojennym apelem opublikowanym przez rosyjski PEN-Club (Русский ПЕНЦентр) Не прогибаться. Не поддаваться лжи (Nie dać się ugiąć. Nie poddawać się kłamstwu). Pod tym pismem swój akces, obok Grigorija Czchartiszwilego, złożyli między innymi pisarze Ludmiła Ulicka, Władimir Wojnowicz, wielu muzyków, filologów, scenarzystów, dziennikarzy i innych reprezentantów twórczej inteligencji ${ }^{27}$.

Dla wielu Rosjan tzw. krymskie referendum z marca 2014 roku i wojna na wschodzie Ukrainy, tocząca się z ukrywanym zaangażowaniem sił zbrojnych Federacji Rosyjskiej, stały się momentem, którego historyczne i moralne znaczenie wywarło determinujący wpływ na krystalizację poglądów Rosjan wobec reżimu ${ }^{28}$. Liberalna inteligencja próbowała bronić niezależności Ukrainy, ale przede wszystkim chyba chronić społeczeństwo rosyjskie, ukazując mu niebezpieczeństwa kroczące za nacjonalistyczną euforią.

${ }^{26}$ Деятели культуры России - в поддержку позиции Президента по украине и Крьму, https://iz.ru/news/567299 (10.03.2021).

${ }^{27}$ Apel Не прогибаться. Не поддаваться лжи, https://www.facebook.com/ penrussia/photos/a.1431614800407784/1449876145248316 (10.03.2021).

${ }^{28}$ Piszący te słowa dobrze pamięta swój czerwcowy pobyt w Rosji w 2014 roku, przy okazji wystąpienia Grzegorza Przebindy w moskiewskim Domu Emigracji Rosyjskiej, notabene na temat jego rozmów z sowieckimi pisarzamidysydentami (Мои встречи с русскими в Париже в 1987-1992 (В. Максимов, Н. Горбаневская, А. Синявский)). Atmosfera entuzjazmu w Moskwie była dość szczególna, na Tagance pojawił się potężny ikoniczny mural z napisem Крым и Россия вместе навсегда (Krym i Rosja razem na zawsze), w kampanii zbierania podpisów do lokalnych wyborów kandydat Szumskij posługiwał się hasłem Вернули Крьм, вернем и Москву без пробок (Przywróciliśmy Rosji Krym, przywrócimy i Moskwę bez korków), a w ówczesnych rozmowach z wieloma zaprzyjaźnionymi Rosjanami - uczonymi, badaczami, znawcami historii, pobrzmiewała wyraźna nuta satysfakcji ze sprawności, z jaką Putin przyłączył Krym do Rosji.

RSL.2021.31.05 s. 13 z 21 
Rzecz jasna takich punktów zwrotnych było już w najnowszej historii Rosji kilka, niewątpliwie jednak w 14 roku prezydentury Putina (z krótkim wyłączeniem na cztery lata kadencji Miedwiediewa w latach 2008-2012) sytuacja polityczna w kraju i regionie miała już szerszy kontekst. Dostrzegł to także Akunin, który swoją decyzję o opuszczeniu Rosji zakomunikował bodaj po raz pierwszy 30 sierpnia 2014 roku we wpisie na swoim blogu w serwisie LiveJournal. Tekst ten był odpowiedzią na pytanie czytelnika:

Z putinowską Rosją nie mam nic wspólnego, wszystko w niej jest mi obce. Być tutaj w czasie ogólnego zaćmienia rozumu stało się ciężko. Dlatego nie zamierzam oczywiście emigrować, ale większą część czasu zacznę spędzać poza granicami Rosji. Trzeźwemu z pijanym niewygodnie pod jednym dachem. Będę od czasu do czasu przyjeżdżać i patrzeć, czy libacja się nie kończy ${ }^{29}$.

Literacki, metaforyczny język tego wpisu, choć brzmi atrakcyjnie, w gruncie rzeczy jest niezwykle oskarżycielski i przygnębiający. Wybrzmiewa tu także interpretacja wizji emigracji, którą ukuł dla siebie pisarz. Wskazuje bowiem, że emigrować faktycznie nie zamierzał, a jedynie postanowił spędzać większość czasu poza granicami Rosji. W sposób dosadny i obrazowy porównał przy tym swą sytuację do znanego powszechnie uczucia osoby niepijącej, której przychodzi spędzać czas w towarzystwie doskonale bawiących się przy alkoholu. Dość bezkompromisowy język tej wypowiedzi, nacechowany jest oczywiście niechęcią wobec współobywateli i trafnie diagnozuje stan rzeczy w postkrymskiej Rosji. Jego opinia zbieżna jest też w całej rozciągłości z poglądem Wiktora Jerofiejewa, który w 2014 roku dostrzegł: „Putin i jego drużyna są bardziej liberalni niż 80 procent narodu rosyjskiego" ${ }^{30}$.

Pisarz niewątpliwie zdaje sobie także sprawę, że w tradycji rosyjskiej zjawisko inteligenckiej emigracji wywołuje silne skojarzenia z przeszłością. Jako poczytny i efektywnie funkcjonujący na rynku wydawniczym pisarz musiał kalkulować w tej sytuacji, że jest

\footnotetext{
${ }^{29}$ Wpis z 30 sierpnia 2014 roku, Во субботу, день ненастный. (Отвечаю на вonpocbl), https://borisakunin.livejournal.com/135653.html (10.03.2021).

${ }^{30}$ Zob. rozmowa Wiktora Jerofiejewa z Grzegorzem Przebindą - W Rosji jest jak w Afryce, „Plus Minus”, 23-24.08.2014.
}

RSL.2021.31.05 s. 14 z 21 
to w pewnym sensie broń obosieczna i być może twarda emigracyjna postawa utrudni mu lub wręcz uniemożliwi, jako kolejnemu „emigracyjnemu pisarzowi”, dotarcie do swych odbiorców. Historia literatury rosyjskiej zna zbyt wiele takich przypadków. Być może te okoliczności sprawiły, że nigdzie wprost nie powiedział, że wybiera los emigranta.

Wydaje się, że pisarz przykrywał stan emigranckiego przygnębienia swojego rodzaju intelektualną grą. Ujawniło się to między innymi w rozmowie z córką Niemcowa, zamordowanego demonstracyjnie tuż przed kolejnymi masowymi antyputinowskimi akcjami protestacyjnymi w Moskwie 27 lutego 2015 roku. Na pytanie Żanny Niemcowej, która notabene sama od śmierci ojca mieszka poza Rosją $^{31}$, czy uważa się za emigranta, odpowiedział:

[...] emigrant to ktoś, kto zdążył wskoczyć na ostatni parowiec do Konstantynopola, bo inaczej konnica Budionnego porąbałaby go szaszkami [rodzaj kaukaskiej, następnie kozackiej szabli, z której chętnie korzystali bolszewicy - B.G.]. Mnie z Rosji nikt nie wypędzał, mogę w dowolnym momencie tam wrócić, nic mi tam nie grozi, dlatego nie uważam się za emigranta, ja jestem ekspatem ${ }^{32}$.

W 2021 roku minie 10 lat od „błotnych”, masowych protestów przeciwko reżimowi Putina. Grigorij Jawliński, najbardziej bodaj znany przedstawiciel liberalizmu we współczesnej Rosji, na 10-lecie pierwszej masowej akcji protestacyjnej skierowanej przeciwko aktualnemu reżimowi, cierpko i dosadnie podsumował aktywizm polityczny minionej dekady i nakreślił kluczowe jego zdaniem sukcesy władzy, przeczące tezom o stopniowym wyczerpywaniu jej mocy sprawczej ${ }^{33}$. Trudno zaprzeczyć faktom. Uliczna opozycja niewiele zyskała. Niestety mimo protestów od 2011 roku reżimowi

${ }^{31}$ Zob. M Gessen, Będzie to, co było. Jak totalitaryzm odradza się w Rosji, przeł. M. Iwińska, H. Faryna-Paszkiewicz, Prószyński i S-ka, Warszawa 2018, s. 643.

${ }^{32}$ Ньнешняя власть ведет мою страну к гибели - Борис Акунин в „Немцова. Интервью", Deutsche Welle на русском, 10.05.2016, https://www. youtube.com/watch?v=YPtnAjW2J8Y (10.03.2021).

${ }^{33} Г$. Явлинский, Без путинизма и популизма. О смыслах текущей политики, 6.02.2021, https://www.yavlinsky.ru/article/bez-putinizma-i-populizma/ (10.03.2021).

RSL.2021.31.05 s. 15 z 21 
dwukrotnie udało się wprowadzić na Kreml Putina jako prezydenta w 2012 i w 2018 roku. Następnie miała miejsce aneksja Krymu i rozlew krwi w Donbasie, a także niejasna wojenna misja w Syrii, angażująca Rosję w trwającą tam od dekady wojnę domową. Podobnie trudne do wyjaśnienia społeczeństwu było włączenie się do kilku konfliktów na kontynencie afrykańskim za pomocą prywatnych firm wojskowych (PMC). W kraju zaś, obok wzmocnienia prezydenta Rosji, przeprowadzono (przez w pełni kontrolowany parlament) pakiet represyjnych i antyobywatelskich ustaw, poprzez korektę konstytucji zorganizowano plebiscyt $\mathrm{w}$ sprawie zmiany ustroju, a w rezultacie zaoferowano Putinowi kontynuację pełnienia funkcji prezydenta właściwie dożywotnio ${ }^{34}$. Z powodzeniem zorganizowano również akcje eliminowania opozycyjnej aktywności, włączając w to próbę fizycznej eksterminacji największych przeciwników władzy.

Być może nakreślony przez Jawlińskiego ponury obraz siły reżimu nie wyklucza realnego osłabienia samego Putina, ale nie zmienia to zasadniczo atmosfery panującej w wolnościowych środowiskach w kraju. Bilans wydarzeń politycznych ostatniej dekady nie jest radosny dla liberalnie i wolnościowo nastawionego pisarza, jakim jest Akunin.

Wydarzenia polityczne i społeczne, jak się wydaje, od przełomowego odnowienia mandatu prezydenckiego Putina w 2012 roku, sprowokowały Akunina do zadania pytań o istotę rosyjskiej państwowości. Historia przestała być dla niego literacką dekoracją i zabawą, w której umocował swą najpopularniejszą postać - Erasta Fandorina. Autor rozrywkowej literatury, beletrysta, jak o sobie często sam mówi, postanowił zostać „prawdziwym pisarzem”, zająć pozycję właściwą dla wielkich rosyjskich twórców, do gremium którego dotąd, z właściwą sobie premedytacją, nie aspirował. Pisarze w kulturze Rosji to tradycyjnie także myśliciele, analitycy polityczni i wizjonerzy. Do ich zadań należą między innymi obserwacja i komentowanie życia publicznego, analiza społeczna, a także w ja-

\footnotetext{
${ }^{34}$ Czysto matematyczne wyliczenia wskazują, że zgodnie z obowiązującym prawem, przy sprzyjających dla Putina okolicznościach, będzie on mógł pełnić najwyższy urząd w Rosji do 84 roku życia.
}

RSL.2021.31.05 s. 16 z 21 
kimś zakresie projektowanie przyszłości. W przypadku pisarstwa Akunina punktem wyjściowym do zakreślenia przyszłości Rosji powinna się stać przemyślana i opowiedziana po nowemu historia tego państwa.

W celu lepszego zrozumienia swego politycznego i społecznego otoczenia Akunin postanowił przepracować, zarówno dla siebie samego, jak i swoich czytelników, dzieje Rosji od czasów najdawniejszych do $1917 \mathrm{roku}^{35}$. W wywiadzie z 2015 roku dla sekcji rosyjskiej BBC stwierdził, że nie jest w stanie zrozumieć kraju, w którym żyje. Szokowało go, że nie pojmuje zachodzących w nim procesów ${ }^{36}$. To właśnie polityka rosyjska czasów najnowszych, zaciskanie autorytarnej pętli i bezskuteczne protesty zmotywowały Akunina do pochylenia się nad historią Rosji z perspektywy pisarza. Twórca formułował swe twarde opinie już po tym, jak do włoskich drukarni, na przełomie 2013 i 2014 roku trafily pierwsze tomy z cyklu „История Российского государства". Dziejopisarstwo Akunina doszło już do ósmego tomu poświęconego drugiej połowie XIX wieku, który pojawił się w rosyjskich księgarniach w ostatnim dniu marca 2021 roku. Uzupełnienie beletrystyczne, zatytułowane Дорога в Китеж (Droga do Kitieżu), trafiło do czytelników na przełomie czerwca i lipca tego roku.

Wedle autorskiej koncepcji, to wielotomowe i wielowarstwowe dzieło ma być opowieścią skierowaną do ludzi, którzy nie interesują się historią, a jego rolą jest mediacja między czytelnikami a faktami z przeszłości. Akunin zastrzegał w wywiadach wielokrotnie, że usiadł do pracy nad tymi tekstami bez żadnych uprzedzeń, ideowych założeń czy gotowych tez. Oczywiście podchodził do tego zadania jako pisarz o liberalnym światopoglądzie. Każdemu tomowi syntezy dziejów Rosji towarzyszy aneks w postaci dzieła

\footnotetext{
${ }^{35}$ Datę graniczną wskazał Akunin jako najbardziej współczesny z możliwych momentów w dziejach Rosji, z którym nie wiążą go bezpośrednie emocje. To stwierdzenie padło w odpowiedzi na jedno z pytań na spotkaniu autorskim po publikacji drugiego literackiego tomu „Истории Российского государства” https://www.youtube.com/watch?v=wIioj0oA4bY (10.03.2021).

${ }^{36}$ Борис Акунин: „Моя страна оккупирована врагом”, https://www.bbc.com/ russian/society/2015/04/150415_boris_akunin_interview (10.03.2021).
}

RSL.2021.31.05 s. 17 z 21 
beletrystycznego, którego akcja osadzona jest w realiach odpowiadających epoce danego tomu historii. W tym pomyśle zawiera się także metoda opowiedzenia społecznej historii Rusi i Rosji. W rolach głównych bohaterów każdego $\mathrm{z}$ beletrystycznych tomów towarzyszących Akunin obsadza postacie pochodzące z jednego rodu, którego znakiem rozpoznawczym jest ciemne znamię w kształcie łzy - swojego rodzaju bindi, znak prawdy - wyraźnie widoczne pośrodku czoła. U Akunina znak ten występuje u bohaterów obojga płci. Jest to galeria wspaniałych, ale i zupełnie zwyczajnych postaci, gdzie obok bohaterów nieprzeciętnie szlachetnych czytelnik odnajduje drobnych szalbierzy i władców okrutników. W sposób szczególny uwidocznione są tu także losy kobiet, perfekcyjnie osadzonych przez pisarza w dziejach Rusi i Rosji. Autor w jednym z esejów, zamieszczonych na blogu dwa tygodnie po zabójstwie Niemcowa napisał, że nie chce, aby autorytarny reżim w Rosji upadł przez to, że Putin odejdzie sam albo w rezultacie pałacowego spisku. Dodał jednocześnie: „chcę, aby autorytarny reżim zmienił się w wyniku świadomego wyboru ludzi, w wyniku ich wspólnego działania" ${ }^{37}$.

Literackie, społeczne i filozoficzne walory Akuninowskich bohaterów z dzieł historycznych, do których narodzin przyczyniły się polityczno-społeczne przeżycia pisarza, zarówno sprzed emigracji, jak i po niej, zasługują jednak w ocenie piszącego te słowa na odrębną, sumienną analizę.

\section{REFERENCES}

Akunin, Boris. "Bokh i Shel'ma." https://www.youtube.com/watch?v=wlioj0oA4bY. Accessed 10 March 2021 [Борис, Акунин. "Бох и Шельма." https://www. youtube.com/watch?v=wIioj0oA4bY. Дата обращения: 10 марта 2021].

Akunin, Boris. "F.A.Q." https://borisakunin.livejournal.com/71491.html. Accessed 10 March 2021 [Акунин, Борис. "F.A.Q." https://borisakunin.livejournal.com/71491.html. Дата обращения: 10 марта 2021].

Akunin, Boris. "Moya strana okkupirovana vragom." https://www.bbc.com/russian/society/2015/04/150415_boris_akunin_interview. Accessed 10 March 2021 [Борис, Акунин. “Моя страна оккупирована врагом.” https://www.

${ }^{37}$ Б. Акунин, О месяце марте и роли личности в истории, wpis z 14 marca 2015 roku, https://borisakunin.livejournal.com/144058.html (10.03.2021).

RSL.2021.31.05 s. 18 z 21 
bbc.com/russian/society/2015/04/150415_boris_akunin_interview. Дата обращения: 10 марта 2021].

Akunin, Boris. "O mesyatse marte i roli lichnosti v istorii." https://borisakunin.livejournal.com/144058.html. Accessed 10 March 2021 [Акунин, Борис. "О месяце марте и роли личности в истории.” https://borisakunin.livejournal. com/144058.html. Дата обращения: 10 марта 2021].

Akunin, Boris. "Ostorozhno, dveri zakryvayut'sya. Sleduyushchaya ostanovka... (zapiski veterana)." https://borisakunin.livejournal.com/139777.html. Accessed 10 March 2021 [Акунин, Борис. "Осторожно, двери закрываются. Следующая остановка... (записки ветерана).” https://borisakunin.livejournal.com/139777.html. Дата обращения: 10 марта 2021].

Akunin, Boris. "Vo subbotu, den' nenastnyy. (Otvechayu na voprosy)." https:// borisakunin.livejournal.com/135653.html. Accessed 10 March 2021 [Акунин, Борис. "Во субботу, день ненастный. (Отвечаю на вопросы).” https:// borisakunin.livejournal.com/135653.html. Дата обращения: 10 марта 2021].

Baryshnikov, Valentin. "Pisatel' Boris Akunin o tom, kak nazyvayet'sya to, chto proiskhodit seychas v Rossii." https://www.svoboda.org/a/24426640.html. Accessed 12 March 2021 [Барышников, Валентин. "Писатель Борис Акунин - о том, как называется то, что происходит сейчас в России." https:// www.svoboda.org/a/24426640.html. Дата обращения: 11 марта 2021].

Bennetts, Mark. Dokopać Kremlowi. Walka rosyjskich dysydentów o odsunięcie Putina od władzy. Transl. Wąsiński, Jan, Wolak, Paweł. Warszawa: Muza S.A. 2014.

Chodorkowski, Michaił. Będę walczył o wolność. Transl. Redlich, Jerzy. Warszawa: Wydawnictwo Albatros A. Kuryłowicz, 2011.

Chodorkowski Michaił, Gieworkian, Natalia. Więzień Putina. Transl. Sowińska, Agnieszka. Warszawa: Agora-Wydawnictwo Czarne, 2012.

"Deyateli kul'tury Rossii - v podderzhku pozitsii Prezidenta po Ukraine i Krymu." https://iz.ru/news/567299. Accessed 10 March 2021 [“Деятели культуры России - в поддержку позиции Президента по Украине и Крыму.” https://iz.ru/news/567299. Дата обращения: 10 марта 2021].

"Dmitriy Peskov: otkaz Borisa Akunina ot uchastiya v litsobranii - 'obshchestvennyy nigilizm." https://www.kommersant.ru/doc/2348322. Accessed 10 March 2021 [“Дмитрий Песков: отказ Бориса Акунина от участия в литсобрании - 'общественный нигилизм.'” https://www.kommersant. $\mathrm{ru} / \mathrm{doc} / 2348322$. Дата обращения: 10 марта 2021].

Gessen, Masha. Będzie to, co było. Jak totalitaryzm odradza się w Rosji. Transl. Iwińska, Magdalena, Faryna-Paszkiewicz, Hanna. Warszawa: Prószyński i S-ka, 2018.

Gołąbek, Bartosz. Anatomia "Runetu." Rosyjskojęzyczny internet jako extra territrorium byłego ZSRR. Krosno: Państwowa Wyższa Szkoła Zawodowa w Krośnie, 2014.

"Interv'yu s Borisom Akuninym - BBC Russian." https://www.youtube.com/watch?v=g3PAJXEiSN8. Accessed 10 March 2021 [“Интервью с Борисом Акуниным - BBC Russian.” https://www.youtube.com/watch?v=g3PAJXEiSN8. Дата обращения: 10 марта 2021].

RSL.2021.31.05 s. 19 z 21 
Jerofiejew, Wiktor, Przebinda, Grzegorz. "W Rosji jest jak w Afryce." Plus Minus, 23-24 Aug. 2014.

"Khodorkovskiy. Bandit Putin, Kuchma s nozhom, tyur'ma, zagovor oligarkhov, Naval'nyy. V gostyakh u Gordona." https://www.youtube.com/watch?v=hqkRgYuaMsg\&t=403s. Accessed 8 March 2021 [“Ходорковский. Бандит Путин, Кучма с ножом, тюрьма, заговор олигархов, Навальный. В гостях у Гордона." https://www.youtube.com/watch?v=hqkRgYuaMsg\&t=403s. Дата обращения: 8 марта 2021].

Kostiuczenko, Jelena. Przyszło nam tu żyć. Reportaże z Rosji. Transl. Kwiatkowska-Moskalewicz, Katarzyna. Wołowiec: Wydawnictwo Czarne, 2020.

Millot, Lorraine. "Avec la Géorgie, 'Poutine agit comme l'empereur Caligula”' https://www.liberation.fr/planete/2006/10/06/avec-la-georgie-poutine-agitcomme-l-empereur-caligula_6429/. Accessed 8 March 2021.

Millot, Lorraine. "Boris Akunin: 'C Gruziyey Putin postupayet, kak imperator Kaligula”' https://inosmi.ru/world/20061009/230352.html. Accessed 8 March 2021 [Лоррен, Мийо. “Борис Акунин: 'С Грузией Путин поступает, как император Калигула"” https://inosmi.ru/world/20061009/230352.html. Дата обращения: 8 марта 2021].

“Ne progibat'sya. Ne poddavat'sya lzhi." https://www.facebook.com/penrussia/photos/a.1431614800407784/1449876145248316. Accessed 10 March 2021 ["He прогибаться. Не поддаваться лжи.” https://www.facebook.com/penrussia/ photos/a.1431614800407784/1449876145248316. Дата обращения: 10 марта 2021].

"Nyneshnyaya vlast' vedet moyu stranu k gibeli - Boris Akunin v 'Nemtsova. Interv'yu.' Deutsche Welle na russkom, https://www.youtube.com/ watch?v=YPtnAjW2J8Y. Accessed 10 March 2021 [“Нынешняя власть ведет мою страну к гибели - Борис Акунин в 'Немцова. Интервью”' Deutsche Welle на русском, https://www.youtube.com/watch?v=YPtnAjW2J8Y. Дата обращения: 10 марта 2021].

"Pryamaya rech': glavnyy redaktor Esquire Filipp Bakhtin.” http://www.lookatme.ru/mag/archive/experience-interview/106931-filipp-bahtin-2010-10-03. Accessed 10 March 2021 [“Прямая речь: главный редактор Esquire Филипп Бахтин.” http://www.lookatme.ru/mag/archive/experience-interview/106931-filipp-bahtin-2010-10-03. Дата обращения: 10 марта 2021].

"Razgovor pisatelya Grigoriya Chkhartishvili (B. Akunin)s Mikhailom Khodorkovskim.” https://old.khodorkovsky.ru/media/8737_Esquire_Interview_ MBK-Rus.pdf. Accessed 8 March 2021 [“Разговор писателя Григория Чхартишвили (Б. Акунин) с Михаилом Ходорковским.” https://old.khodorkovsky.ru/media/8737_Esquire_Interview_MBK-Rus.pdf. Дата обращения: 8 марта 2021].

"Soderzhaniye Khodorkovskogo v SIZO Chity prodleno do 2 fevralya 2009 goda." https://www.newsru.com/russia/08Oct2008/mike.html. Accessed 10 March 2021 [“Содержание Ходорковского в СИЗО Читы продлено до 2 февраля 2009 года.” https://www.newsru.com/russia/08Oct2008/mike.html. Дата обращения: 10 марта 2021]. 
Sokolov, Mikhail. "Boris Nemtsov: 'Lozungi momenta: 'Vor ne dolzhen sidet' v Kremle'; 'Ni odnogo golosa Vladimiru Putinu 4 marta!'; 'Ne pustim Putina vovtoroy tur vyborov!'” www.svoboda.org/a/24435229.html. Accessed 8 March 2021 [Соколов, Михаил. “Борис Немцов: 'Лозунги момента: 'Вор не должен сидеть в Кремле'; 'Ни одного голоса Владимиру Путину 4 марта!'; 'Не пустим Путина во второй тур выборов!'” www.svoboda.org/a/24435229.html. Дата обращения: 8 марта 2021].

"V Moskve proshla 'kontrol'naya progulka' s pisatelyami." https://www.bbc.com/ russian/russia/2012/05/120513_moscow_progulka. Accessed 10 March 2021 [“В Москве прошла 'контрольная прогулка' с писателями.” https://www. bbc.com/russian/russia/2012/05/120513_moscow_progulka. Дата обращения: 10 марта 2021].

Vinogradov, Yegor. "Protesty na Bolotnoy: miting zavershen, chto dal'she?" https://p.dw.com/p/13QVM. Accessed 12 March 2021 [Виноградов, Егор. “Протесты на Болотной: митинг завершен, что дальше?” https://p.dw.com/p/13QVM. Дата обращения: 12 марта 2021].

"Vystupleniye Borisa Akunina na Bolotnoy." https:/www.youtube.com/watch?v=Md8G3pSX91E. Accessed 11 March 2021 ["Выступление Бориса Акунина на Болотной.” https://www.youtube.com/watch?v=Md8G3pSX91E. Дата обращения: 11 марта 2021].

Yavlinskiy, Grigoriy. "Bez putinizma i populizma. O smyslakh tekushchey polityki." https://www.yavlinsky.ru/article/bez-putinizma-i-populizma/. Accessed 10 March 2021 [Явлинский, Григорий. “Без путинизма и популизма. О смыслах текущей политики.” https://www.yavlinsky.ru/article/bez-putinizma-i-populizma/. Дата обращения: 10 марта 2021]. 